\title{
Nigerian Environment under Siege and the Effect on the Management of Tertiary Institutions for Peace and Security
}

\author{
Victor O. Ebuara \\ Department of Educational Administration and Planning, University of Calabar, Calabar
}

Doi:10.5901/mjss.2014.v5n27p269

\section{Abstract}

The purpose of this paper was to examine the effect of insecurity on the management of tertiary education in Nigerian environment. To address this problem, three research hypotheses were formulated to guide the study. The instrument used for the study was a four point likert type self developed questionnaire, which was validated and tested for rehability by experts and administered on 499 sampled staff and students of Federal tertiary education institutions in Northern Nigeria. Data collected was analysed using one way analysis of variance (ANOVA). The major result obtained were that without a well planned and developed educational institutions devoid of insecurity academic peace and work can hardly be possible. Based on the result, it was recommended that educational institutions should seek peace through the introduction of peace education programme in which the content emphasis deconstruction of structures of violence and introduction of structures for peace and security.

Keywords: Nigerian environment; tertiary institutions; peace; security; education

\section{Introduction}

Ordinarily the concepts of siege and peace have been interrupted to mean a situation which involved military or police operation towards the defense of the nation and its environment. This development calls for a condition of social harmony that is, where there are no social antagonisms. In other words a condition or environment in which there is no social conflict and individuals, groups are able to meet their needs and expectations. This is the real or complete peace and security that will be addressed in this paper, since the school environment should include absence of war (direct violence, siege) and absence of an unjust structure (indirect violence) before peace and security can exist.

Peace according to Ebuara and Ekpoh (2011) implies that in whatever form, level or environment it operates or managed, what is relevant, is that peace is the greatest factor facilitating institutional management towards sustenance of performance. This is because in environment under siege always Witnesses little or no investment in education sector.

Taking a cursory look at the on-going occurrences in our nation with particular reference to states and educational institution in northern Nigeria environment, there are very clear indications that the environment is under siege. In other words, a state of insecurity exist in a form(s) of kidnapping, hostages bombing, rape, robbery and waton destruction of life and property (Biodund and Aliyal 2013). This situation has recently assumed frightening dimensions as it has extended into the environment of educational institutions thereby disrupting existing peace and academic work.

According to an erstwhile Head of State, Abubakar (2004) in a paper on the challenges of security in Nigeria, he observed that, the greatest threat to the present civilian dispensation is insecurity. That the challenge to the survival of democracy in Nigeria is security issues and problems that have affected the attitude, confidence and co-operation of the public in peace maintenance.

In support of above contention, Oyebode (2011) in his analysis on the imperative of security, affirmed that, it is selfevident that without security, hardly is anything possible. It is obvious that in the face of these problems, the goals and standard of education has continued to be largely unachievable for tertiary educational institutions to attain a level of development, and for peace and environmental security need to be properly addressed in this situation. Ogunyemi and Aliyu (2011) suggest that one sure way of takling the insecurity situation in our environment to day is to accord the field of psychology a pride of place in policy formulation and implementation to promote national cohesion and integration. To this end, the researcher is of the opinion that security issues should go beyond law and order by encompassing meaningful existence for the survival of institutions and environment. This has become pertinent in the sense that security is stability and continuity of livelihood, predictability of relationships, feeling safe and having the confidence of belonging. All these benefits in the existence of peace and security will no doubt reduce the frequent insurrections that has become permanent features of our nations history. 
It is also pertinent to note that to successfully addressed this insecurity problem, our educational system that is the bed-rock of training and transformation of behaviours must be given adequate attention and pride of place in our society.

\section{Statement of the Problem}

Peace management in our environment is crucial for the development and progress of the nation. Peace and security are no doubt complementing goods that are essential for the growth of any social organization. But recent occurrences in our particularly in northern states of the country clearly show that peace and security does not exist and the state of insecurity put in place has assumed frightening dimension. In Nigeria today, much have been said and written about the issue of insecurity and the attendant crisis, conflict and violence with their concomitant effects on peace management. In this period of uncertainty, numerous individuals and groups have advocated various proposals for ensuring peace through dialogue, amnesty, confrontation, border closure, separation or war, but none has been put in place or succeeded. The country and educational institutions are still facing major internal crisis and hostility feuding in the environment. The effect of this development on peace is better imagined than described.

It is obvious at this juncture that in the face of these problems, peace has eluded the affected environment and has continued to be largely unachievable. It appears that there is something fundamentally wrong with the country and the people. The search and inculcation of peace has therefore become imperative and need to be urgently addressed.

\section{Research Questions}

The following research questions guided the study

1. To what extent does environmental uncertainty affects peace management.

2. To what extent does the existing internal security crisis affects peace management.

3. To what extent does the hostile environment affect peace management.

4. To what extent does existing violence affects peace managements.

\section{Research Hypotheses}

The following hypotheses were formulated to guide the study.

1. There is no significant influence of environmental uncertainty on peace management

2. There is no significant influence of the existing internal security crisis on peace management.

3. There is no significant influences of hostile environment on peace management

4. There is no significant influence of existing violence on peace management.

\section{Research Methodology}

The design adopted in this study was survey method. This method involve collection of data from a sample of tertiary institutions staff in northern Nigeria. The population of this study comprised all the staff and students of only federal tertiary institutions. Data was collected from the states and federal tertiary institutions that are currently experiencing crisis and violence.

These states and institutions are Bornu State, Adamawa State and Yobe State respectively with their federal tertiary institutions of University of Maidugri, University of Technology, University of Yobe.

Proportionate stratified random sampling technique was adopted in selecting 396 staff and students for the study. The tertiary institutions were stratified on the basis of their locations and operations. Three tertiary institutions in three states were selected out of the nine (9) states in northern Nigeria from the selected 132. Federal universities staff and students each were randomly picked. This gave a total sample size of 396 respondents.

A self-developed questionnaire was used in this study. The instrument entitled Nigerian Environment under siege and the effect on peace management in tertiary on peace management in tertiary in institutions in northern Nigeria (UEUSEPMTIMNNQ). The questionnaire was made up of two parts. Part one was the biographic data of the respondents such as educational location and work experience, part two consist of 67 items on peace management effort. The items in the questionnaire were structured on 014 point Likert scale. 


\section{Validation and Reliability of the Instrument}

In this study, face validity was used for measurement. The researcher presented the initial draft of the instrument with the research questions to colleagues, lecturers and educational management experts, in the education faculty. After examining the instrument they made some corrections which the researcher effected in the final draft of the instrument.

To determine the reliability of the instrument, a trial test was conducted to estimate the reliability, the researcher administered the copies of the questionnaire on 499 tertiary institution staff in selected universities of northern Nigeria. Their responses to the instrument were collated and analysed accordingly. The instrument yields a coefficient value of 0.80 which the research considered satisfactory for the study.

\section{Method of Data Collection}

The copies of the questionnaire were administered on the sampled respondents in their institutions through the help of research assistants some of the copies were collected on the same day they were administered. However, repeated visits were made in where it was impossible to retrieved.

\section{Method of Data Analysis}

In this section the hypotheses were subjected to analysis using one way analysis of variance (ANOVA) statistical tool after administration of the questionnaire on the respondents.

\subsection{Hypothesis one}

There is no significant influence of environmental uncertainty on peace management.

Table 1. (ANOVA) showing influence of environmental uncertainty on peace management.

\begin{tabular}{lccccccc}
\hline Variables & $\mathrm{N}$ & $\mathrm{X}$ & $\mathrm{SD}$ & $\mathrm{T}$-cal & $\mathrm{Df}$ & T-tab & Decision \\
\hline Environmental uncertainty & 313 & 24.71 & 4.42 & 2.599 & 497 & 1.645 & Sign \\
Peace management & 186 & 25.69 & 3.59 & & & & \\
\hline T-value is significant at 0.05 level & & & & & & &
\end{tabular}

Table one above shows that there is a significant influence of uncertainty of environment on peace management. The tcalculated value of 2.599 is by far greater that the t-tabulated value of 1.645 . this suggest that crisis environment influence on peace management is significant. From the table an environment that experiences crisis seen to be difficult for peace to be successfully managed.

\subsection{Hypothesis Two}

There is no significant influence of internal security crisis on peace management.

Table 2. ANOVA showing influence of internal security crisis on peace management.

\begin{tabular}{lccccccc}
\hline Variables & $\mathrm{N}$ & $\mathrm{X}$ & $\mathrm{SD}$ & $\mathrm{T}$-cal & $\mathrm{Df}$ & T-tab & Decision \\
\hline Internal security crisis & 313 & 22.34 & 4.93 & 3.729 & 497 & 1.645 & \\
Peace management & 186 & 24.06 & 5.09 & & & & \\
\hline
\end{tabular}

$\mathrm{T}$-vale is significant at 0.05 level.

Table 2 shows there is a significant influence of internal security crisis on the management of peace.

T-calculated value of 3.729 is by far greater than the t-tabulated value of 1.645. This indicated that the influence of internal security crisis on peace management is significant. The result on the table revealed that respondents generally agreed that when there is internal security crisis, peace management effort becomes very difficult if not impossible in the educational system. 


\subsection{Hypothesis Three}

There is no significant influence of hostile environment on the management of peace.

Table 3. ANOVA showing influence of hostile environment on peace management.

\begin{tabular}{lccccccc}
\hline Variables & $\mathrm{N}$ & $\mathrm{X}$ & $\mathrm{SD}$ & $\mathrm{T}$-cal & $\mathrm{Df}$ & $\mathrm{T}$-tab & Decision \\
\hline Hostile environment & 296 & 23.99 & 5.24 & 5.21 & 497 & 1.645 & Significant \\
Peace management & 203 & 21.53 & 4.38 & & & & \\
\hline
\end{tabular}

$\mathrm{T}$-value is significant at 0.05 level.

Results from table 3 reveals that there is significant influence of hostile environment on peace management. This is so because the T-calculated value of 18 is far greater than the T-table valued of 1.645 on the management of peace.

\section{Discussion of Findings}

In hypothesis 1 the result is significant in the sense that crisis environment influences the management of peace in the society. It is self-evidence that without environmental security hardly is any academic work possible especially in the school system. This observation is in line with Ezeoha (2001) research study on causes and effects of insecurity in Nigerian environment, where he concluded that security and peaceful environment implies, stability and continuity of livelihood, predictability of relationships, feeling safe and making progress.

Hypothesis two analysis revealed that internal security crisis influence the management of peace in educational system. This result agreed with Oyebode (2003) who argued that the strength, wealth and security of the internal organization and administration of tertiary educational institutions goes beyond maintenance of law and order. The impression one gets is that aggressive situation needs a collaborative approach and effort of education managers to address the internal security crisis with diplomacy and maturity.

From hypothesis three the result revealed that hostile education environment makes governance of the system impracticable in address of the challenge to the survival of democracy in Nigerian environment Aliyu (2007) maintained that hostile environment is capable of affecting the effort attitude interest, confidence and cooperation of all groups and segments that make up the administration of tertiary education institution.

\section{Conclusion}

The dynamic nature of education and its environment has indeed made it imperative for adequate security to be enforced for the purpose of sustainable development of the society. The study also revealed that there is influence of insecurity on the management of tertiary education system manifesting in a form of rape, kidnapping corruption and misappration of increases the government in collaboration with the educational institution management should see insecurity as one of the major tasks, that should be handled with severity and dexterity so as to save the nation and the institutions from total collapse.

\section{Recommendations}

1. Since peace and security are complementary goods that are essential for successful management of education system; there is need for the government and education managers to introduce peace education conferred programmes that will change the attitude and orientation in training of people towards peaceful living and maintenance of security in the society.

2. The should be a conducive educational climate always that can harbor effective development of peace education in various higher institutions.

3. Higher educational institution should be constitutionally mandated to produce only people who can function effectively in the maintenance of peace and security in the society.

4. Educational institution administrators should educate people through regular seminars to stop supporting peace-destroying educational initiations and embrace peace building effort.

5. For positive peace building to succeed in our society, educational institutions should seek to deconstruct structures of violence and construct structures for peace and security. 


\section{References}

Abubakar, A. (2004) Basic Concepts Issues and Strategies peace and Conflict Resolutions Nigeria African conflict case studies. Enugu: Keny and Brothers.

Aliyu, M. K. (2007). Global and historical purview of terrorism in Developing Nations. Kebi: government press.

Biodun, O. and Aliyu, M. K. (2011). Nigeria under siege in the scholar, Vol. 8, (2)4-8.

Ebuara, V. O. and Ekpoh (2001). The need for peace in the Management of tertiary institutions in South-South of higher Education studies 1(2) 4-8

Ezeoha, C. (2001). Conflict Reduction, Management and Resolution in conflict resolution in African, F. M. Deng. Washington Dc: Brookings Institute 29.

Ogunyemi, B. and Aliyu, M. K. (2011) Is Nigeria under siege? The National scholar 8;(2)4-8.

Oyebade J. B. (2003) Military Occupation and Social Stratification: An Inaugural lecture: University of Ibadan.

Oyebade, J. B. (2011). Universities in Africa Strategies for Stabilization and Revitalization World Bank Technical paper number 194. 